\title{
Galvanic coupling effects for module-mounting elements of ground-mounted photovoltaic power station
}

\author{
Boguslaw Pierozynski ${ }^{1}$, Henryk Bialy ${ }^{2}$ \\ ${ }^{1}$ University of Warmia and Mazury in Olsztyn, Department of Chemistry, Faculty of Environmental Protection and \\ Agriculture, Plac Lodzki 4, 10-727 Olsztyn, Poland \\ ${ }^{2}$ Corab Limited, M. Kajki 4, 10-547 Olsztyn, Poland \\ "Corresponding author: e-mail: bogpierozynski@yahoo.ca; boguslaw.pierozynski@uwm.edu.pl
}

\begin{abstract}
This communication reports on the concerns associated with possible generation of galvanic coupling effects for construction materials that are used to manufacture mounting assemblies for ground-mounted photovoltaic (PV) power stations. For this purpose, six macro-corrosion galvanic cells were assembled, including: hot-dip $\mathrm{Zn} /$ Magnelis®-coated steel/Al and stainless steel (SS)/Al cells. Corrosion experiments involved continuous, ca. threemonth exposure of these couplings in $3 \mathrm{wt} \% \mathrm{NaCl}$ solution, conducted at room temperature for a stable $\mathrm{pH}$ value of around 8. All corrosion cells were subjected to regular assessment of galvanic current-density and potential parameters, where special consideration was given to compare the corrosion behaviour of $\mathrm{Zn}$-coated steel samples with that of Magnelis ${ }^{\circledR}$-coated electrodes. Characterization of surface condition and elemental composition for examined materials was carried-out by means of SEM and EDX spectroscopy techniques.
\end{abstract}

Keywords: PV mounting assembly, Zn-coated steel, Magnelis ${ }^{\circledR}$ coating, galvanic coupling.

\section{INTRODUCTION}

Ground-mounted assemblies of photovoltaic (PV) power station modules generally consist of frames attached to mounting supports, which typically include concreteembedded pole mounts. The PV solar modules are typically designed to last 25-30 years; thus, similar durability (mechanical and corrosion-related) is also expected from structural components of the photovoltaic system. Key elements of the PV racking arrangement include different metals and metal composites, namely: Zn-coated steel, $\mathrm{Al}$ sheets and profiles, stainless steel (SS) and copper fasteners ${ }^{1-3}$. A phenomenon of galvanic corrosion typically takes place when two dissimilar metals (or alloys) in a galvanic series are connected in the presence of electrolyte. An anode is more negative than a cathode in the galvanic series and thus it undergoes dissolution (anodic oxidation process), whereas oxygen $\left(\right.$ or $\mathrm{H}_{3} \mathrm{O}^{+}$) reduction proceeds at the cathode side. Generally, the further apart the metals are in the galvanic series, the greater the corrosion potential in the galvanic cell would be. However, the rates of electrochemical reaction between two metals are strictly dependent on electrolyte composition and its $\mathrm{pH}$, and ambient temperature ${ }^{4-7}$. Hence, as the galvanic coupling between the two metals could significantly increase the corrosion rate of the anode, it is of superior importance that electrically shorted metal parts are not susceptible to galvanic corrosion.

In this work, we have examined the galvanic coupling behaviour for most representative couplings that could be found in PV-based installations. These included: hotdip $\mathrm{Zn}\left(\right.$ Magnelis $\left.{ }^{\circledR}\right)$-coated steel//Al and $\mathrm{SS} / / \mathrm{Al}$ galvanic couples, corrosion-tested at room temperature in $3 \mathrm{wt}$. $\% \mathrm{NaCl}$ solution, a typical corrosion test electrolyte. Magnelis ${ }^{\circledR}$ is an innovative, composite $\mathrm{Zn}$-based metallic coating, modified with 3.5\% $\mathrm{Al}$ and 3\% Mg. Magnelis ${ }^{\circledR}$ was originally introduced by ArcelorMittal company and as such it offered superior to typical $\mathrm{Zn}$ coatings protection in a number of corrosion environments ${ }^{8}$.

\section{EXPERIMENTAL}

The work described in this communication involved characterization of the galvanic coupling effects for six galvanic cells, which imitate the PV structure/fastening connections, as described below:

1. Magnelis ${ }^{\circledR}$-coated steel (S250GD: 1.0242 grade)// $\mathrm{Al}_{\text {ox }}$ (oxidized aluminum alloy);

2. Magnelis ${ }^{\circledR}$-coated steel (S250GD: 1.0242 grade)// $\mathrm{Al}_{\mathrm{EF}}$ (electrophoretically-coated aluminum alloy);

3. Hot-dip Zn-coated steel (DD11: 1.0332 grade) $/ / \mathrm{Al}_{\text {ox }}$;

4. Hot-dip Zn-coated steel (DD11: 1.0332 grade)//Al $\mathrm{Al}_{\mathrm{EF}}$;

5. AISI $304 \mathrm{SS}(304 / 0 \mathrm{H} 18 \mathrm{~N} 9) / / \mathrm{Al}_{\text {ox }}$;

6. AISI $304 \mathrm{SS}(304 / 0 \mathrm{H} 18 \mathrm{~N} 9) / / \mathrm{Al}_{\mathrm{EF}}$;

Samples of commercial Zn(Magnelis ${ }^{\circledR}$ )-coated steel sheets, aluminum and stainless steel specimens were prepared as follows:

- Hot-dip Zn-coated steel: $50 \times 50 \times 3.15$ mm (ca. 80-90 $\mu \mathrm{m}$ Zn thickness);

- Magnelis $\AA_{-}$-coated steel: $50 \times 50 \times 3.02 \mathrm{~mm}$ (ArcelorMittal; ca. 25-30 $\mu \mathrm{m}$ thick coating);

- $\mathrm{Al}_{\text {ox }}$ (anodized $\mathrm{Al}$ 6063-T6 alloy): $50 \times 50 \times 3.85 \mathrm{~mm}$, where $\mathrm{Al}$ anodization procedure was carried-out potentiostatically $(0.5-1.0 \mathrm{~V} / \mathrm{SCE}$ for constant charge of $1 \mathrm{C}$ versus $\mathrm{Pb}$ sheet counter electrode) in $2 \mathrm{~mol} \mathrm{dm}^{-3} \mathrm{H}_{2} \mathrm{SO}_{4}$ solution at $20^{\circ} \mathrm{C}$;

- $\mathrm{Al}_{\mathrm{EF}}$ (styrene-acrylate copolymer, industrial electrophoretic coating on $\mathrm{Al} 6005-\mathrm{T} 5$ alloy): $50 \times 50 \times 5.93$ $\mathrm{mm}$ and

- AISI 304 SS (304/0H18N9): $30 \times 30 \times 5.01 \mathrm{~mm}$.

All metal samples were initially degreased with ethanol, dried in exicator and weighed on a Sartorius CP224-OCE precision balance with $0.1 \mathrm{mg}$ accuracy. Electrical connections to electrodes were provided by means of threaded steel wires, covered with shrinkable PE tubes (all electrode corners were properly taped with a polymer, acid resistant adhesive tape). The galvanic cells were then assembled by wire connecting the respective electrode pairs (with an electrode-to-electrode distance equal to $50 \mathrm{~mm}$ ). The corrosion exposure was realized in $3 \mathrm{wt}$. $\%$ sodium chloride solution, prepared by dissolution of 
$\mathrm{NaCl}$ salt (Polish Chemical Compounds, p.a.) in distilled water, in glass beakers at room temperature and an average $\mathrm{pH}$ value of 8 for a total period of 89 days.

Corrosion measurements for examined galvanic couplings involved intermittent recording of their mixed corrosion potentials $\left(E_{\text {cor }}\right)$ and anode, and cathode open circuit potentials $(o c p)$ measured vs. saturated calomel electrode (SCE), where sufficient time was allowed between the measurements in order for the electrodes to completely depolarize. In addition, intensity of galvanic coupling current $\left(I_{\mathrm{gc}}\right)$ was periodically evaluated through the so-called ZRA (zero resistance ammeter) mode of the Solartron 12.608 W Full Electrochemical System, consisting of 1260 frequency response analyzer (FRA) and 1287 electrochemical interface (EI). The latter System was also employed to carry-out occasional linear polarization experiments, which involved electrode micro-polarizations conducted at $\pm 10 \mathrm{mV}$ around the open circuit (corrosion) potential, at a scan-rate of $0.10 \mathrm{mV} \mathrm{s}^{-1}$. On the other hand, electrode potential measurements were conducted by means of Fluke 85 III multimeter; oxygen content, electrolyte conductivity and $\mathrm{pH}$ evaluations were then performed with HI 9146, HI 9835 and HI 2002-01 meters from Hanna Instruments, correspondingly.
Furthermore, SEM/EDX spectroscopy analyses were carried-out for unexposed and corrosion-tested metal samples by means of Merlin FE-SEM microscope (Zeiss), equipped with Bruker XFlash 5010 EDX instrumentation (with $125 \mathrm{eV}$ resolution).

\section{RESULTS AND DISCUSSION}

\section{Spectroscopic examination of unexposed and corrosion- -tested metal samples}

Figures 1 through 3 and Table 1 below present the results of surface spectroscopy (SEM/EDX) examinations of fresh and the corrosion-tested (for 89 days), selected constituents of galvanic couples, namely: anodes - Magnelis ${ }^{\circledR}$-coated (Sample A) and hot-dip Zn-coated (Sample B) steel sheets, and a cathode - oxidized Al 6063-T6 alloy (Sample C). Hence, it could be seen in Table 1 that fresh surface of Magnelis ${ }^{\circledR}$ coating is primarily composed of $\mathrm{Zn}$ (ca. 65 wt.\%), $\mathrm{Al}(6 \%), \mathrm{Mg}$ (3\%), C (9\%) and oxygen (14\%) elements. Extended exposure of Magnelis $\AA$-coated steel electrode (Sample A) in a galvanic coupling with anodized Al 6063-T6 alloy in $3 \%$ sodium chloride solution led to a gradual depletion of zinc, aluminum and magnesium elements

Table 1. Surface EDX elemental analysis for unexposed and corrosion-tested Magnelis ${ }^{\circledR}$-coated (Sample A), hot-dip Zn (Sample B) and oxidized Al 6063-T6 alloy (Sample C) materials

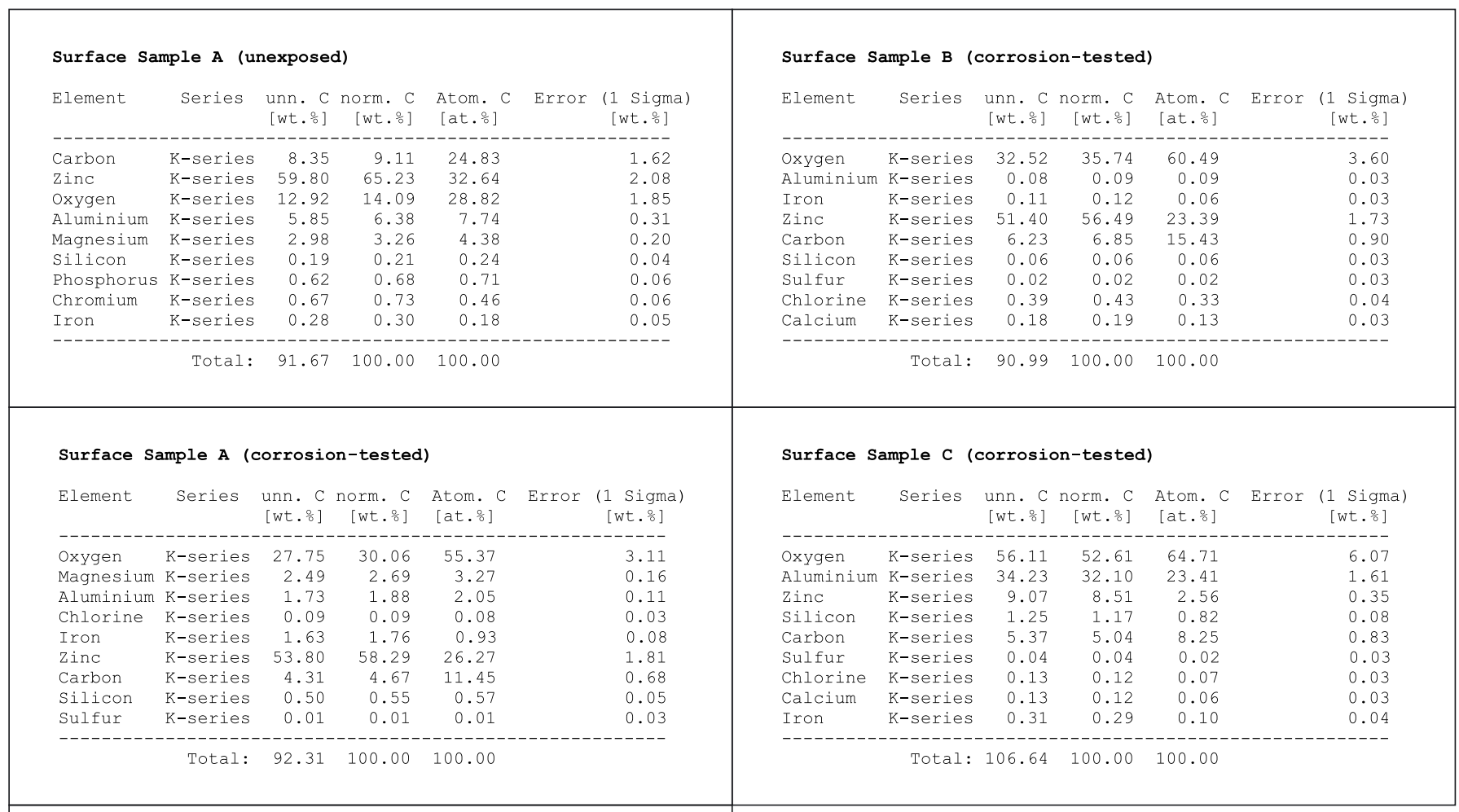

\begin{tabular}{|c|c|c|c|c|c|c|}
\hline Element & Series & $\begin{array}{l}\text { unn. C } \\
\text { [wt. 응] }\end{array}$ & $\begin{array}{r}\text { norm. C } \\
\text { [wt. \% ] }\end{array}$ & $\begin{array}{l}\text { Atom. C } \\
{\left[\text { at. } \frac{\circ}{\circ}\right]}\end{array}$ & Error & $\begin{array}{c}\text { (1 Sigma) } \\
\left.\text { [wt. } \frac{\circ}{0}\right]\end{array}$ \\
\hline Carbon & K-series & 10.71 & 11.69 & 38.10 & & 2.24 \\
\hline Zinc & K-series & 72.64 & 79.24 & 47.45 & & 2.51 \\
\hline Oxygen & K-series & 4.87 & 5.32 & 13.01 & & 0.99 \\
\hline Aluminium & K-series & 0.47 & 0.51 & 0.74 & & 0.06 \\
\hline Iron & K-series & 0.16 & 0.17 & 0.12 & & 0.04 \\
\hline Lead & M-series & 2.83 & 3.08 & 0.58 & & 0.15 \\
\hline
\end{tabular}


a)

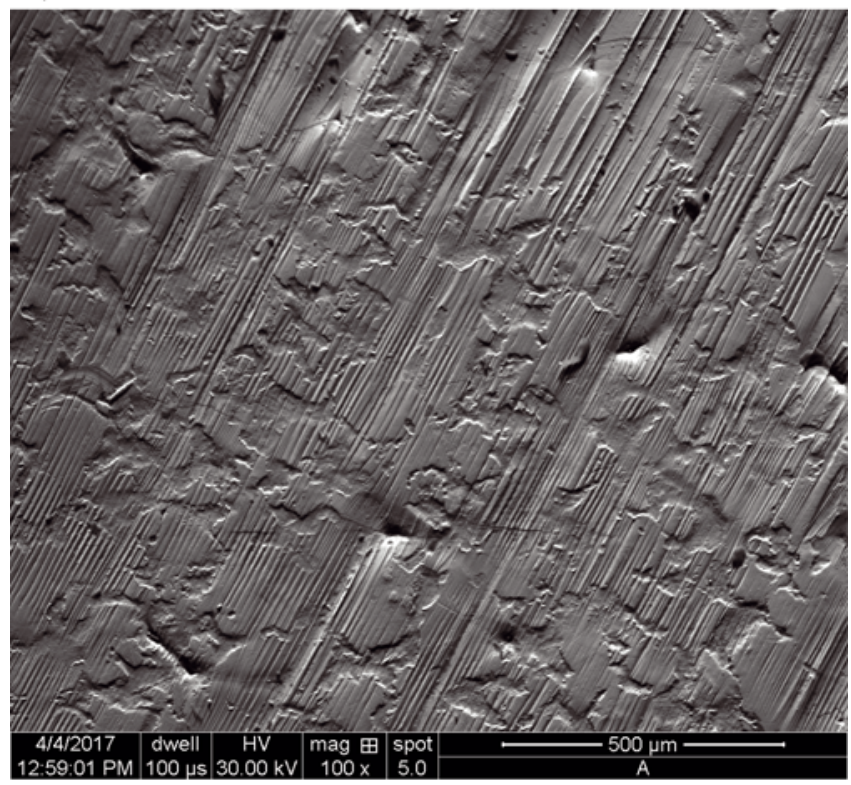

b)

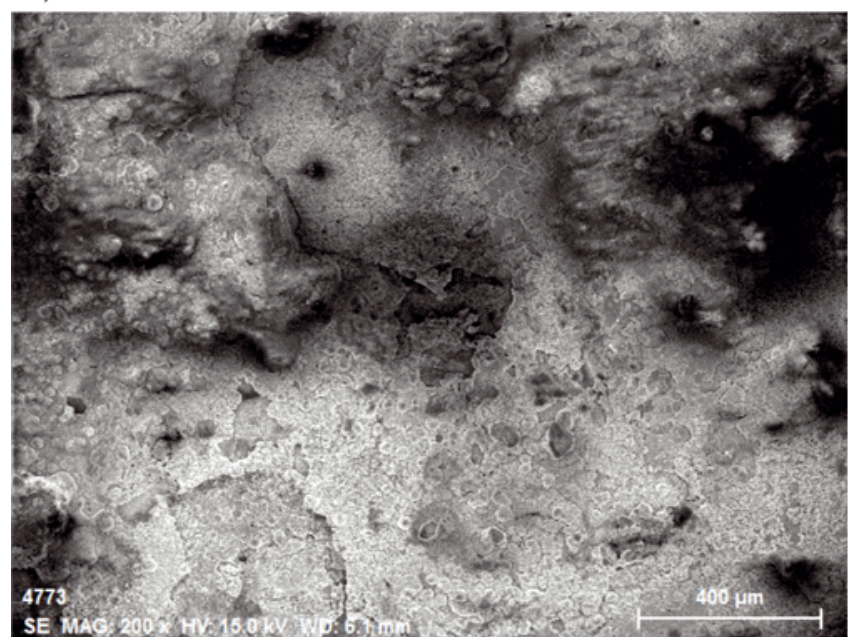

c)

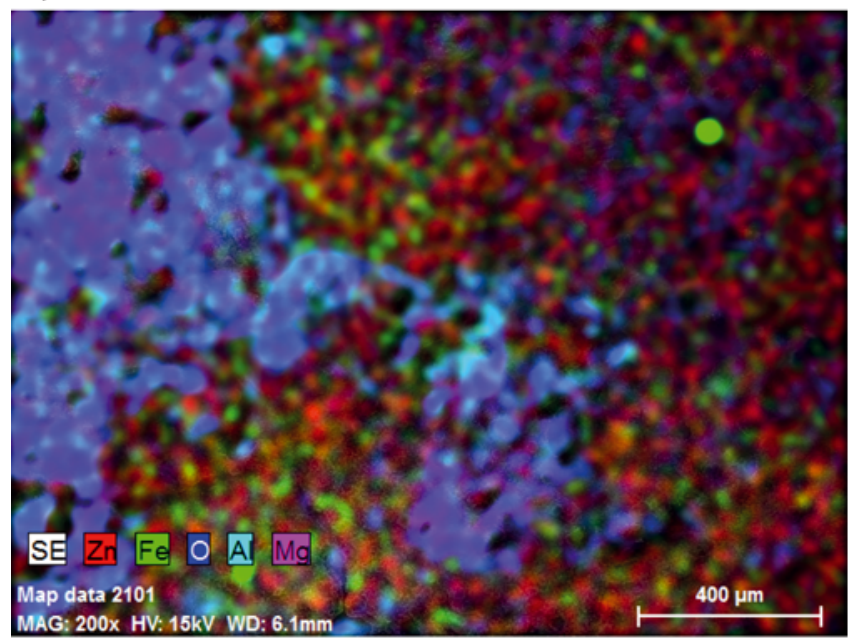

Figure 1. a) SEM micrograph picture of Magnelis ${ }^{\circledR}$-coated carbon steel surface, taken at $100 \times$ magnification for a fresh electrode; b) As in (a) above, but taken at $200 \times$ magnification for corrosion-tested electrode; c) As in (b) above, but EDX mapping

along with a radical increase of oxygen and iron surface concentrations. The latter could be supported by the analysis of EDX elemental mapping in Figure 1c. Similar observations could be made for Sample B, where consi- a)

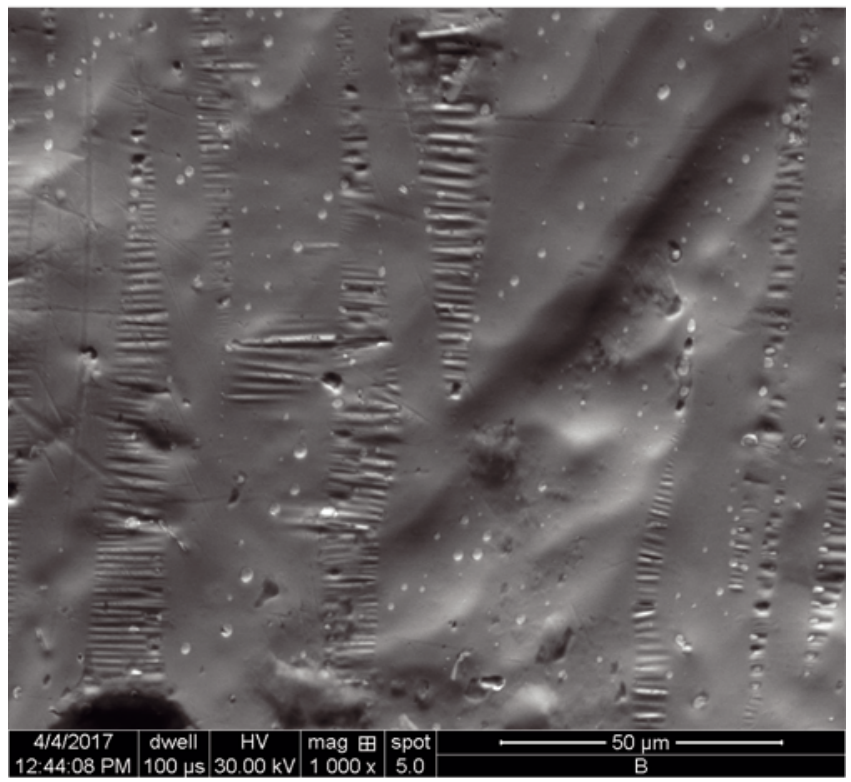

b)

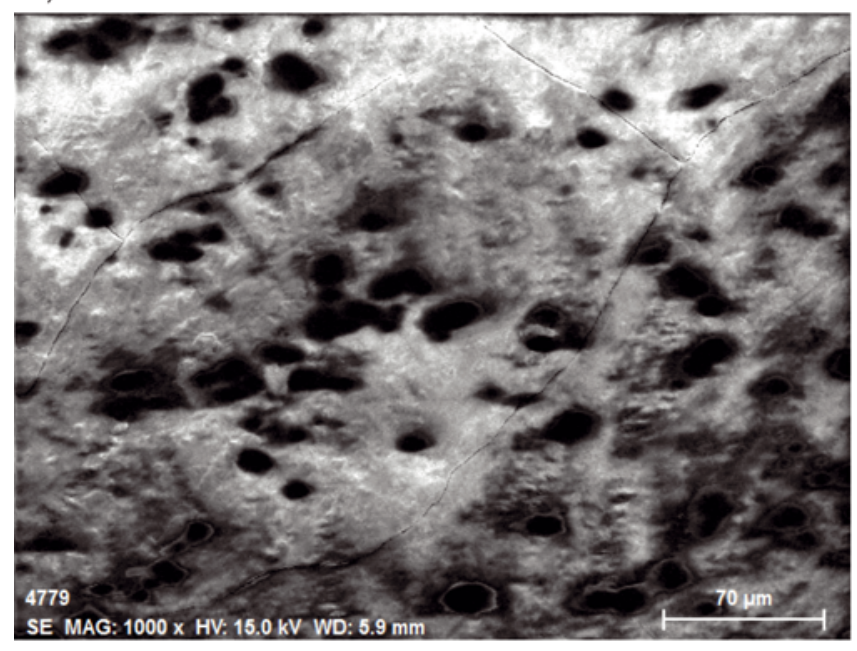

c)

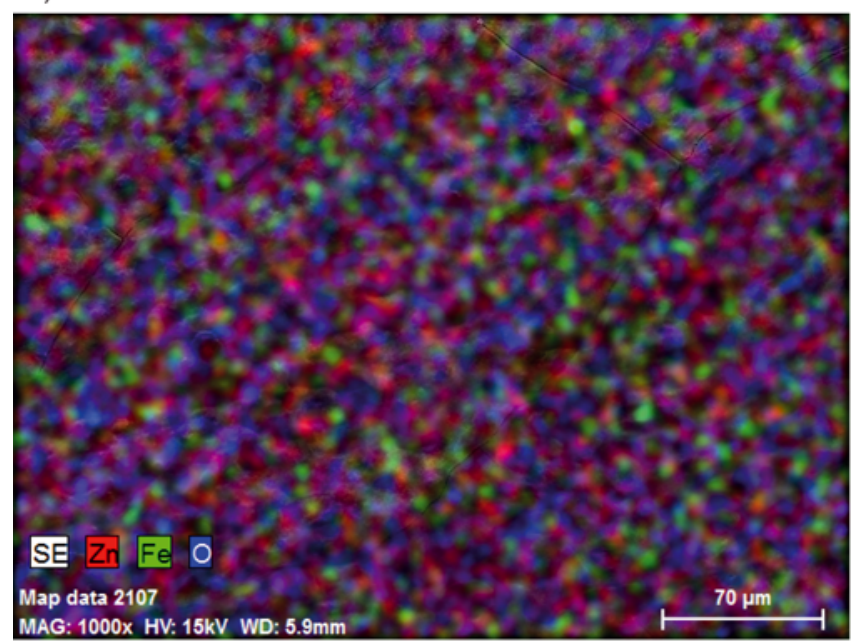

Figure 2. a) SEM micrograph picture of hot-dip Zn-coated carbon steel surface, taken at $1000 \times$ magnification for a fresh electrode; b) As in (a) above, but taken for corrosion-tested electrode; c) As in (b) above, but EDX mapping

derable surface oxidation along with the presence of $\mathrm{Fe}$ for $\mathrm{NaCl}$-exposed electrode might clearly be discerned in the EDX micrograph picture of Figure 2c. However, the most important observation that could be deduced from 
comparison of SEM micrographs of fresh Magnelis®/ Zn-coated steel samples (Figs. 1a and 2a, respectively) with those of the corrosion-tested electrodes (Figs. 1b and $2 \mathrm{~b}$, correspondingly) is that extended electrode exposure in sodium chloride solution resulted in significant surface accumulation of porous (especially manifested in Fig. 2b) corrosion products. These deposits typically create stable surface layers, which then contribute to hampering oxygen diffusion to the metal coating. On the other hand, prolonged corrosion exposure of the cathode side (oxidized Al 6063-T6 alloy) resulted in deposition of significant amount ( $c a .8 .5$ wt.\%) of $\mathrm{Zn}$ element on the electrode surface (refer to Table 1 again and to Figs. 3a, and 3b).

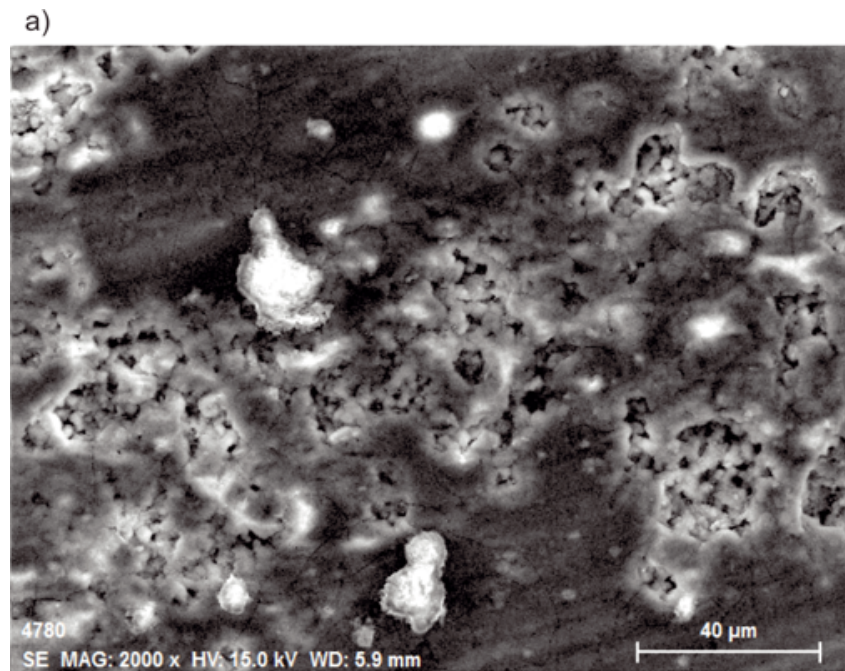

b)

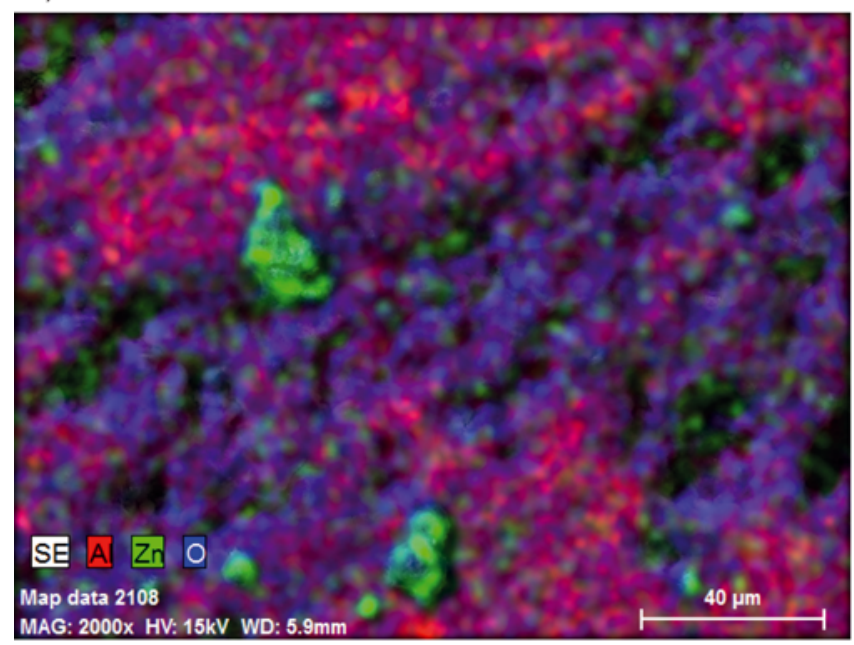

Figure 3. a) SEM micrograph picture of oxidized $\mathrm{Al}$ 6063T6 alloy surface, taken at $2000 \times$ magnification for corrosion-tested electrode; b) As in (a) above, but EDX mapping

\section{Corrosion characteristics of galvanic couplings}

Initially, the corrosion performance of fresh and $\mathrm{NaCl}$-exposed (after 38 days of free corrosion exposure) Magnelis ${ }^{\circledR}$ and Zn-coated carbon steel electrodes was examined by means of the linear polarization method. The latter allowed for the derivation of polarization resistance $\left(R_{\mathrm{p}}\right)$ and the corrosion current-density $\left(j_{\text {cor }}\right)$ parameters, as shown in Table 2 below. The polarization resistance was calculated as the inverse of the slope of $I$ (current) vs. $E$ (potential) graph, based on above-mentioned micro-polarization measurements. The corrosion current $\left(I_{\text {cor }}\right)$ was then derived from the well-known Stern-Geary relationship (equation 1):

$$
I_{c o r}=\frac{b_{a} b_{c}}{2.303 R_{p}\left(b_{a}+b_{c}\right)}
$$

When Tafel slopes $\left(b_{\mathrm{a}}\right.$ and $\left.b_{\mathrm{c}}\right)$ of $120 \mathrm{mV}$ decade $^{-1}$ are used, this equation simplifies to $I_{\text {cor }}=0.026 \times R_{\mathrm{p}}^{-1}$. Thus, when compared to Magnelis ${ }^{\circledR}$ material, hot-dip Zn coating is characterized by significantly increased corrosion current-densities (on the order of 9 and $14 \mu \mathrm{A} \mathrm{cm}^{-2}$ for fresh and the corrosion-tested samples, respectively) and the reduced values of the $R_{\mathrm{p}}$ parameter - around 2860 and $1840 \Omega \mathrm{cm}^{2}$, correspondingly (see Table 2). Obtained corrosion current-densities could then be re-calculated to linear corrosion rates $\left(V_{\mathrm{L}}\right)$, according to equation 2 below:

$V_{L}=8.76 \times 10^{6} \frac{k_{Z n} I_{c o r}}{S_{A} d_{Z n}} \quad / \mu$ year $^{-1} /$

where: $\mathrm{k}_{\mathrm{Zn}}$ is the electrochemical equivalent for $\mathrm{Zn}$ in /g $\mathrm{A}^{-1} \mathrm{~h}^{-1} /$,

$I_{\text {cor }}$ is measured corrosion current in $/ \mathrm{A} /$,

$\mathrm{S}_{\mathrm{A}}$ is electrode's geometrical surface area in $/ \mathrm{m}^{2} /$ and $\mathrm{d}_{\mathrm{Zn}}$ is density of zinc in $/ \mathrm{kg} \mathrm{m}^{-3} /$.

Hence, the linear corrosion rates assessed at an initial stage of the corrosion process in sodium chloride solution came to about 64 and $137 \mu \mathrm{m}_{\text {year }}{ }^{-1}$ for Magnelis® type and hot-dip $\mathrm{Zn}$ coatings, correspondingly. The above implies that any of these coatings would only last about 6 months under such aggressive experimental conditions. However, it should be stressed that due to significant surface accumulation of corrosion products, comparative evaluation of corrosion rates by the loss of electrode mass (on the order of 0.2 and 0.4 wt.\% for Magnelis $®$ and hot-dip $\mathrm{Zn}$ coatings, respectively, in reference to $\mathrm{Al}_{\text {ox }}$ cathodes and the corrosion exposure period of 89 days) was not feasible.

On the other hand, the corrosion characteristics of galvanic couplings are presented in Figsures 4 and 5 below. Hence, for all galvanic couples built by connecting Magnelis ${ }^{\circledR}$ (or $\mathrm{Zn}$ )-coated steel sheet with aluminum electrodes, the former exhibited anodic, whereas the latter ones cathodic behaviour (see Fig. 4a). In addition, the

Table 2. Calculated average corrosion parameters for hot-dip Zn-coated and Magnelis ${ }^{\circledR}$-coated carbon steel electrodes, in contact with 3 wt.\% NaCl solution (two electrodes were examined for each composite at days: 0 and 38), obtained through linear polarization measurements $\left( \pm 10 \mathrm{mV}\right.$ around the $o c p$, at a sweep rate of $\left.0.10 \mathrm{mV} \mathrm{s}^{-1}\right)$.

\begin{tabular}{|l|c|c|c|}
\hline Materials & $E_{\text {cor }} / \mathrm{mV}$ & $R_{\mathrm{p}} / \Omega \mathrm{cm}^{2}$ & 6083 \\
\hline Magnelis $®(\mathrm{~d}=0)$ & -1052 & $j_{\mathrm{cor}} / \mu \mathrm{A} \mathrm{cm}$ & 4.3 \\
\hline Magnelis $(\mathrm{d}=38)$ & -1058 & 3423 & \\
\hline Hot-dip Zn $(\mathrm{d}=0)$ & -1054 & 2857 & 7.6 \\
\hline Hot-dip Zn $(\mathrm{d}=38)$ & -1036 & 1836 & 9.1 \\
\hline
\end{tabular}


corrosion potential $\left(E_{\mathrm{cor}}=-1025\right.$ to $\left.-1036 \mathrm{mV}\right)$ approached open circuit potential of respective anodes, giving evidence that oxygen reduction reaction (equation 3 ) on the surface of aluminum cathode constitutes the corrosion control step ${ }^{\mathbf{9 - 1 2}}$.

$\mathrm{O}_{2}+2 \mathrm{H}_{2} \mathrm{O}+4 e^{-} \rightarrow 4 \mathrm{OH}^{-}$

Furthermore, major corrosion product for zinc coating involves formation of zinc hydroxide (stabilized by increased $\mathrm{pH}$ value upon the cathodic reaction), which then becomes converted to $\mathrm{ZnO}$, according to equation $4: 9,10,13-15$

$$
\mathrm{Zn}^{2+}+2 \mathrm{OH}^{-} \rightarrow \mathrm{Zn}(\mathrm{OH})_{2(s)} \rightarrow \mathrm{ZnO}_{(s)}+\mathrm{H}_{2} \mathrm{O}
$$

The presence of $\mathrm{Mg}$ and $\mathrm{Al}$ additives within Magnelis ${ }^{\circledR}$ coating also leads to the formation of other and complex corrosion products (see e.g. Refs. 10 and 13 for details). The lowest value of the galvanic current-density parameter ( $c a .0 .04 \mu \mathrm{A} \mathrm{cm} ~^{-2}$ upon 89 days of the exposure, see Fig. 4b) was exhibited by the Cell 1 (Magnelis ${ }^{\circledR}$-coating as anode vs. oxidized $\mathrm{Al}$ cathode), which also coincided with the minimum ocp potential difference between the electrodes (about $27 \mathrm{mV}$, Fig. 4a). Progressive cathodic polarization of the aluminum cathodes observed for both Magnelis $₫$-based galvanic

a)

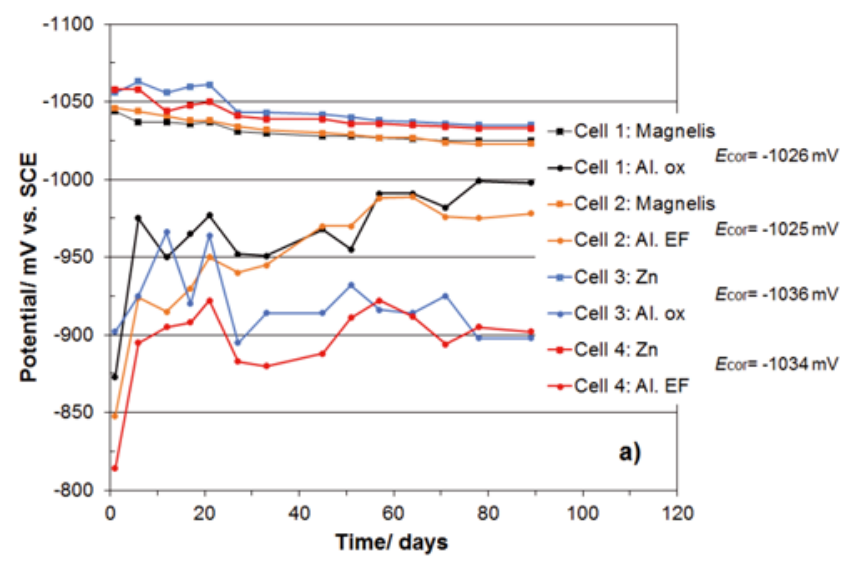

b)

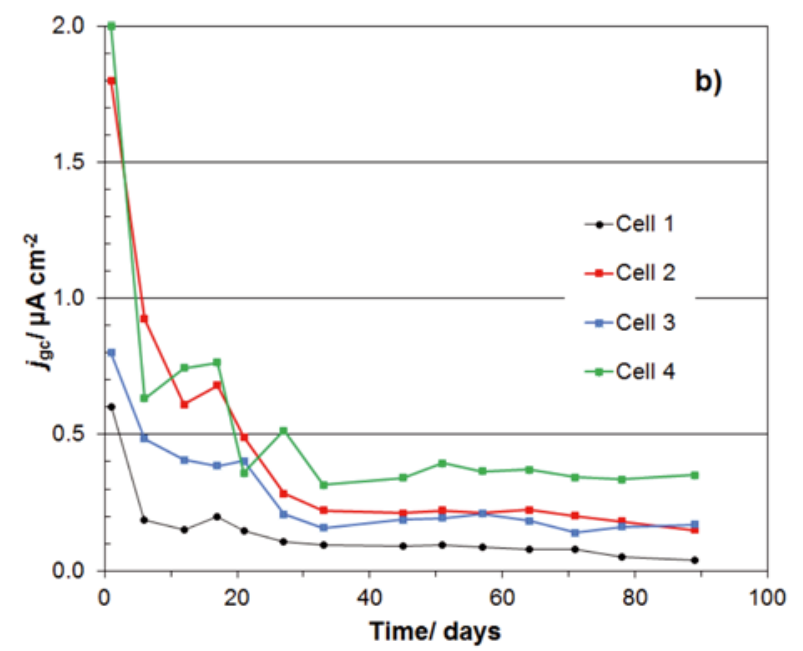

Figure 4. a) Open circuit and corrosion potentials in function of exposure time for corrosion-tested galvanic couplings (Cells 1 through 4) in 3 wt.\% NaCl solution; b) As in (a) above, but galvanic couple current-density for stated Cells in function of exposure time a)

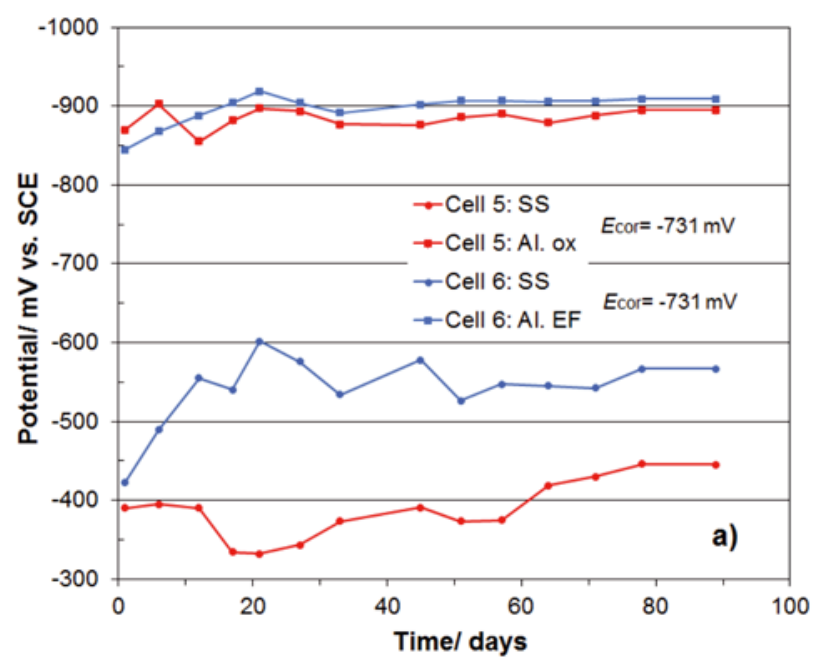

b)

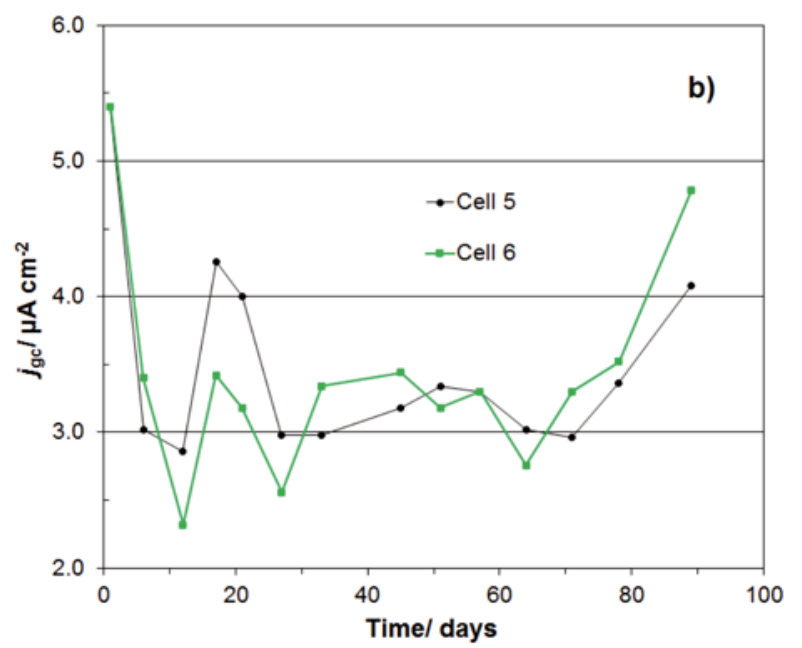

Figure 5. a) Open circuit and corrosion potentials in function of exposure time for corrosion-tested galvanic couplings (Cell 5 and Cell 6) in 3 wt.\% $\mathrm{NaCl}$ solution; b) As in (a) above, but galvanic couple current-density for stated Cells in function of exposure time

cells most likely results from increased deposition of $\mathrm{Zn}$ (or perhaps also $\mathrm{Mg}$ ) element on the Al surface, as previously shown in Figures $3 \mathrm{a}$ and $3 \mathrm{~b}$ and Table 1 .

In order to assess the effect of galvanic coupling current on the rate of general corrosion for Magnelis $₫$-type and hot-dip Zn coatings, average values of the $I_{\mathrm{gc}}$ parameter for the Cells 1 through 4 become incorporated into the equation 2 to derive the corresponding linear corrosion rates for these coatings. Thus, the calculated corrosion rates came to: 1.6, 3.2, 2.7 and $5.5 \mu \mathrm{m}$ year $^{-1}$ for the Cells: 1, 2, 3 and 4, respectively. In other words, under experimental conditions $(3 \% \mathrm{NaCl}, \mathrm{pH}$ range: 7.9-8.3, temperature: $16-18^{\circ} \mathrm{C}$, dissolved $\left[\mathrm{O}_{2}\right]=7.1-7.3 \mathrm{ppm}$ and electrolyte conductivity, $x=30-35 \mathrm{mS} \mathrm{cm}^{-1}$ ), the increase of general corrosion rate due to galvanic coupling is insignificant and comes to about $3.7 \%$ for Magnelis $®$ and $3.0 \%$ for the hot-dip $\mathrm{Zn}$ coating.

On the contrary, the Cells denoted as 5 and 6 (SS cathode vs. $\mathrm{Al}_{\mathrm{Ox} /} \mathrm{Al}_{\mathrm{EF}}$ anode) exhibited radically larger ocp voltages (Fig. 5a) and galvanic current-densities (Fig. 5b) than those recorded for the Cells 1 through 4. As a result, the calculated linear corrosion rate (due to the galvanic coupling effect) for aluminum anode 
(with appropriate changes of $\mathrm{k}$ and $\mathrm{d}$ parameters in equation 2 in order to account for $\mathrm{Al}$ ) approached 40 $\mu \mathrm{m}$ year $^{-1}$, where $\mathrm{Al}(\mathrm{OH})_{3}$ is a major corrosion product ${ }^{11}$ (equation 5):

$$
4 \mathrm{Al}+3 \mathrm{O}_{2}+6 \mathrm{H}_{2} \mathrm{O} \rightarrow 4 \mathrm{Al}(\mathrm{OH})_{3}
$$

In addition, the corrosion process in the case of SS/Al galvanic cells is also controlled by the cathodic reduction of oxygen (compare the recorded mixed corrosion potential value of $-731 \mathrm{mV}$ with those of the corresponding open circuit anode potentials in Fig. 5a).

\section{CONCLUSIONS}

Zinc-coated steel and aluminum sheets, and stainless steel fasteners are regularly used structural materials to build ground-mounted photovoltaic power stations. Laboratory-based galvanic coupling experiments conducted in 3 wt. $\% \mathrm{NaCl}$, self-aerated solution confirmed that the galvanic coupling currents produced by $\mathrm{Zn}$ (Magnelis®)coated steel coupled with aluminium cathodes stand just for several per-cent of the corrosion rate increase. In addition, Magnelis $\AA^{\circledR}$ coating exhibits significantly reduced corrosion rates, as compared to regular hot-dip zinc coating. The latter proves to be in effect for both examined galvanic couples, as well as freely corroding $\mathrm{Zn}$-based metal coatings, which is most likely the effect of surface formation of more insoluble and less permeable to oxygen corrosion products, favoured by Magnelis@'s $\mathrm{Mg}$ and $\mathrm{Al}$ additives.

Hence, from the technical point of view it seems rather safe to use electrically connected $\mathrm{Zn}$ (or Magnelis ${ }^{\circledR}$ ) coatings with $\mathrm{Al}$ surfaces under employed experimental conditions. However, it should also be understood that variable environmental conditions (e.g. sporadic removal of surface corrosion deposits by rainfall, changing $\mathrm{pH}$ and dissolved oxygen level for atmospheric precipitation) could periodically (and significantly) increase the galvanic coupling currents.

On the other hand, galvanic couples between stainless steel and aluminum parts should rather be avoided in practice. These cells revealed radically greater current-densities, where sole galvanic coupling effect for aluminum loss could be estimated at $40 \mu \mathrm{m}$ year $^{-1}$.

\section{LITERATURE CITED}

1. Aste, N. \& Pero, C.D. (2010). Technical and economic performance analysis of large-scale ground-mounted PV plants in Italian context. Prog. Photovoltaics 18(5), 371-384. DOI: 10.1002/pip. 984 .

2. Desideri, U., Proietti, S., Zepparelli, F., Sdringda, P. \& Bini, S. (2012). Life cycle assessment of a ground-mounted $1778 \mathrm{~kW}_{\mathrm{p}}$ photovoltaic plant and comparison with traditional energy production systems. Appl. Energy 97, 930-943. DOI: 10.1016/j.apenergy.2012.01.055.

3. Yang, R.J. (2015). Overcoming technical barriers and risks in the application of building integrated photovoltaics (BIPV): hardware and software strategies. Automat. Constr. 51, 92-102. DOI: 10.1016/j.autcon.2014.12.005.

4. Fontana, M.G. (1987). Corrosion Engineering, $3^{\text {rd }}$ ed., McGraw-Hill, New York, Chapter 3, p. 39.

5. Roberge, P.R. (2000). Handbook of Corrosion Engineering, McGraw-Hill, New York, Chapter 5, p. 340.
6. Uhlig, H.H. \& Revie, R.W. (1985). Corrosion and Corrosion Control: An Introduction to Corrosion Science and Engineering, $3^{\text {rd }}$ ed., John Wiley \& Sons, New York, Chapter 6, p. 101.

7. Kautek, W. (1988). The galvanic corrosion of steel coatings: aluminum in comparison to cadmium and zinc. Corr. Sci. 28(2), 173-199. DOI: 10.1016/0010-938X(88)90094-7.

8. Magnelis ${ }^{\circledR}$, industry.arcelormittal.com/magnelis, last accessed (07/04/2017).

9. Hamlaoui, Y., Pedraza, F. \& Tifouti, L. (2007). Comparative study by electrochemical impedance spectroscopy (EIS) on the corrosion resistance of industrial and laboratory zinc coatings. Am. J. Appl. Sci. 4(7), 430-438. DOI: 10.3844/ ajassp.2007.430.438.

10. Salgueiro Azevedo, M., Allely, C., Ogle, K. \& Volovitch, P. (2015). Corrosion mechanisms of $\mathrm{Zn}(\mathrm{Mg}, \mathrm{Al})$ coated steel in accelerated tests and natural exposure: 1 . The role of electrolyte composition in the nature of corrosion products and relative corrosion rate. Corr. Sci. 90, 472-481. DOI: 10.1016/j. corsci.2014.05.014.

11. Hakansson, E., Hoffman, J., Predecki, P. \& Kumosa, M. (2017). The role of corrosion product deposition in galvanic corrosion of aluminum/carbon systems. Corr. Sci. 114, 10-16. DOI: 10.1016/j.corsci.2016.10.011.

12. Sun, H., Liu, S. \& Sun, L. (2013). A comparative study on the corrosion of galvanized steel under simulated rust layer solution with and without 3.5 wt. $\% \mathrm{NaCl}$. Int. J. Electrochem. Sci. 8, 3494-3509.

13. Diler, E., Rouvellou, B., Rioual, S., Lescop, B., Nguyen Vien, G. \& Thierry, D. (2014). Characterization of corrosion products of $\mathrm{Zn}$ and $\mathrm{Zn}-\mathrm{Mg}-\mathrm{Al}$ coated steel in a marine atmosphere. Corr. Sci. 87, 111-117. DOI: 10.1016/j.corsci.2014.06.017.

14. Hamlaoui, Y., Pedraza, F. \& Tifouti, L. (2008). Corrosion monitoring of galvanised coatings through electrochemical impedance spectroscopy. Corr. Sci. 50, 1558-1566. DOI: 10.1016/j. corsci.2008.02.010.

15. Liu, Y., Li, H. \& Li, Z. (2013). EIS Investigation and Structural Characterization of Different Hot-Dipped ZincBased Coatings in $3.5 \% \mathrm{NaCl}$ Solution. Int. J. Electrochem. Sci. 8, 7753-7767. 